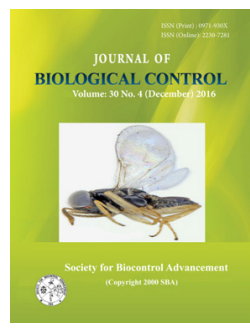

\title{
Potential natural enemies of the invasive rugose spiraling whitefly, Aleurodicus rugioperculatus Martin in India
}

\author{
K. SELVARAJ*, R. SUNDARARAJ ${ }^{1}$, T. VENKATESAN, CHANDISH R. BALLAL, S. K. JALALI, ANKITA \\ GUPTA and H. K. MRUDULA \\ ICAR-National Bureau of Agricultural Insect Resources, Hebbal, Bengaluru - 560024, Karnataka, India \\ ${ }^{1}$ Institute of Wood Science and Technology, Malleswaram, Bengaluru - 560003, Karnataka, India \\ *Corresponding authorE-mail: selvaentomo@yahoo.co.in
}

\begin{abstract}
A invasive rugose spiraling whitefly (RSW) Aleurodicus rugioperculatus Martin (Hemiptera:Aleyrodidae) was found infesting coconut, banana, custard apple and several ornamental plants in Tamil Nadu, Andhra Pradesh and Kerala for the first time in India. The identity of the pest species was determined through morphological and molecular tools. Furthermore cytochrome c oxidase-I gene (658 bp) of RSW was sequenced (GenBank accession number KY209909) which would serve as an ideal molecular diagnostic marker for its identification irrespective of its phenotypic plasticity. During the survey, several natural enemies were recorded and maximum parasitism was recorded by Encarsia guadeloupae Viggiani (Hymenoptera: Aphelinidae) and its COI gene was sequenced and deposited as Encarsia sp. (GenBank accession number KY223606). Per cent parasitism ranged from 20.0 to $60.0 \%$ in different collection locations, highest parasitism being recorded in Kerala as compared to other states. The predators recorded were Mallada sp., few coccinellids and predatory mites. This communication is the first report of the rugose spiraling whitefly, its host plant range and associated natural enemies in India.
\end{abstract}

KEY WORDS: Aleurodicus rugioperculatus, host-plants and natural enemies, invasive pest, spiraling whitefly

(Article chronicle: Received: 20.12.2016; Revised: 30.12.16; Accepted: 31.12.2016)

\section{INTRODUCTION}

Recently, a invasive rugose spiraling whitefly (RSW), Aleurodicus rugioperculatus Martin (Hemiptera: Aleyrodidae) has entered India and reported on coconut palm (Cocos nucifera L.) for the first time during August-September, 2016 at Pollachi taluk, Coimbatore district in Tamil Nadu by Sundararaj and Selvaraj (In press). RSW was originally described from Belize in 2004 on coconut (Martin, 2004) and initially reported from Miami-Dade County, Florida, United States of America from gumbo limbo Burera simaruba (L.) Sarg in 2009 as a pest. This whitefly is believed to have originated from Central America and it incidence was confirmed from 22 countries in Central and North America limited to Belize, Mexico, Guatemala and Florida (Evans, 2008). RSW is a highly polyphagous pest, which has been found to feed on 118 plant species which include edible plants, palms and weeds (Stocks, 2012) and it has been classified as a serious threat for coconut cultivation in Florida (Stocks and Hodges, 2012; Kumar et al., 2013). In coconut, RSW prefers to colonize on hybrid and dwarf varieties, especially Chowghat orange dwarf, Malay- sian orange dwarf and Ganga Bondam semi-dwarf. RSW was observed to colonize almost each and every part of the coconut palm including inflorescence, exocarp and entire under surface of leaf lamina and bunch of banana.

Identification and documentation of the pest, its spread in different agro-ecological zones, host plant range of RSW and its natural enemies are pre-requisites to develop integrated pest management strategies for the pest and also would be very useful to develop viable mass production as well as conservation strategies of the natural enemies. As RSW is invasive to India, systematic and continuous surveys need to be carried out to understand the distribution, host plant range, and natural enemies. The identification of whiteflies is mainly based on the fourth larval instar, also called 'puparium', which show high polymorphism with extreme plasticity in key morphological characters that vary according to the host plant, thus making the taxonomy of whiteflies a highly challenging task. DNA based taxonomy is in current use to identify known and unknown species on the basis of the pattern of nucleotide arrange- 
ment in a fragment of DNA, which is not only serving as a complementary tool to conventional alpha taxonomy for confirming the identity of the species but also in delineating the cryptic species in the population (Hebert et al., 2004).

\section{MATERIALS AND METHODS}

\section{Survey}

Systematic and continuous surveys were carried out in different locations in Tamil Nadu, Kerala, Andhra Pradesh and Karnataka to understand the distribution, host plant range, and natural enemies of RSW in India. During the survey, under surface of the infested plant parts coconut and banana were examined and intensity of damage was assessed randomly on five palms/plants in three locations. Puparia and adults of whitefly were collected separately and observed for the emergence of natural enemies. Percent parasitization was determined based on total number of pupae having exit holes/colony divided by total number of pupae per colony. Adults of RSW and associated natural enemies were collected in vials with $70 \%$ alcohol and used for identification through morphological as well as for developing the DNA based identification.

\section{Identification and material examined}

Identification of RSW and its natural enemies were done through both conventional taxonomy as well as cytochrome c oxidase I (COI) based molecular confirmation at the Molecular Entomology Division of ICAR-NBAIR. Whitefly puparial samples collected from each host plant and location were processed for mounting. Best mounts were used for conformity of the species. The RSW specimens collected from different locations were examined for conformity as follows; India: Tamil Nadu, Pollachi, Coconut Research Station, Aliyar nagar from coconut, 10 puparia on 5 slides; banana 10 puparia on 5 slides; bird of paradise 10 puparia on 5 slides; custard apple 10 puparia on 5 slides; Kerala, Palakkad and Kottayam, 10 puparia on 5 slides each from coconut and banana collected by first author; Andhra Pradesh, Rajamundry, 10 puparia on 5 slides each from coconut and banana collected by S. K. Jalali.

For identification of parasitoid, Viggiani (1987) and Hayat (2011) were consulted. Predators were identified based on feeding of immature stages of RSW under field conditions. Similarly host plants were identified at Mahatma Gandhi Botanical Garden, UAS, GKVK, Bengaluru. For molecular identification, genomic DNA was extracted from single whitefly and parasitic adult using Qiagen DNeasy ${ }^{\circledR}$ Kit, following the manufacturer's protocols. The extracts were subjected to PCR amplification of a $658 \mathrm{bp}$ region near the 5 ' terminus of the COX I gene following standard protocols. The amplified products were sequenced by $\mathrm{M} / \mathrm{s}$ Eurofins, Bengaluru and the same were uploaded to GenBank after annotation.

\section{RESULTS AND DISCUSSION}

\section{Identification of Aleurodicus rugioperculatus and host plants}

The best mounts were obtained from the pupal case and the identity was confirmed as described by Martin (Martin, 2004). The studied specimens were in the collection of ICAR-NBAIR. Besides, a $658 \mathrm{bp}$ size COI gene was amplified and sequenced. The sequence was submitted to GenBank under accession number KY209909. Our sequence matched $99 \%$ with the available sequence of $\mathrm{A}$. rugioperculatus accession number KP032219 submitted from Florida, USA (Dickey et al., 2015), thereby confirming the identity of the pest.

During the survey, different stages of RSW were recorded on coconut palm (Cocos nucifera L.), banana (Musa acuminata L., M. balbisiana L.), bird of paradise (Strelitzia reginae Aiton) and custard apple (Annona sp.) and egg stage was only observed on areca palm/butterfly palm (Dypsis lutescens), Phoenix roebelenii O' Brien, and oleander (Nerium oleander L.) (Plate 1). Among the host plants, coconut and banana are the most preferred. Similar observations were also recorded in several countries including Florida (Stocks, 2012; Stocks and Hodges, 2012; Francis et al., 2016).

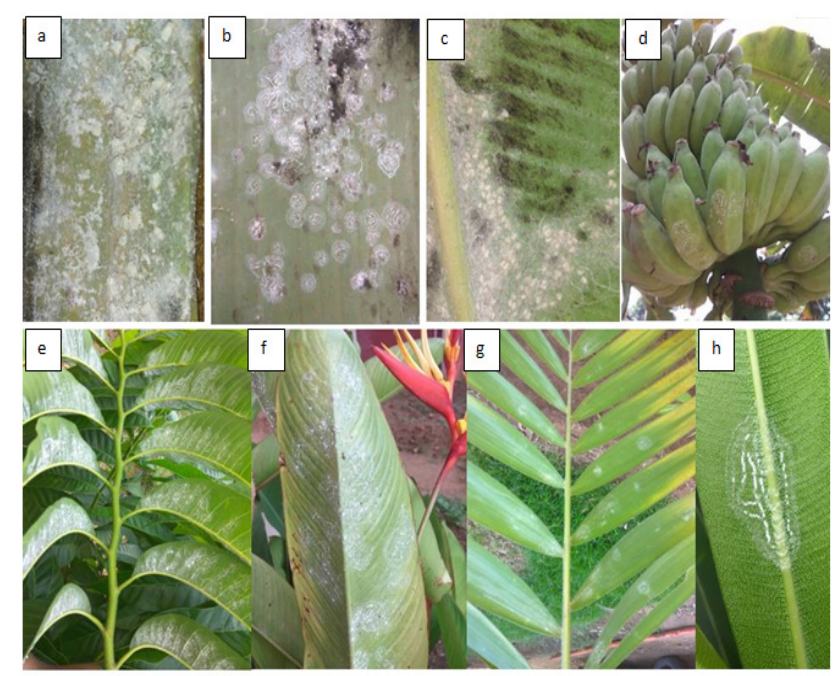

Plate 1. a. Coconut; b-d. Banana; e. Custard apple; f. Bird of paradise; g. Butterfly palm; h. Oleander. 


\section{Identification of natural enemies}

Natural enemies such as parasitoids and predators including predatory mite and coccinellids associated with RSW were recorded (Plate 2). The most commonly found natural enemies are green lacewing (Mallada spp.) and Encarsia guadeloupae Viggiani (Hymenoptera: Aphelinidae). Key diagnostic characters of female E. guadeloupae are: body dark brown, except side lobes of mesoscutum and scutellum; mid lobe largely dark brown; axillae brown; TVII yellow or brown laterally; third valvula pale yellow. Wings hyaline, hind coxa and femur dark brown, legs otherwise pale yellow to white. Antennal formula, 1142; clava as long as last two funicle segments. Mesoscutum with usually 9 pairs of setae (sometimes with variable number of setae, 15-20); scutellum with two pairs of setae; axillae normally with one setae each (Plate 3B). Fore wing basal cell with 3 setae before parastigma. Mid tarsi-4 segmented; fore and hind tarsi-5 segmented. Similarly, E. guadeloupae and Encarsia sp. were recorded as potential parasitoids of many whiteflies including RSW (Evans, 2008: Taravati et al., 2013; Francis et al., 2016). Furthermore, the COI gene (658 bp) of the parasitoid was amplified, sequenced and deposited as Encarsia sp. (GenBank Acc. No. KY223606). The per cent parasitism ranged from $20.0-60.0 \%$ in different locations, with highest parasitism recorded in Kerala as compared to other surveyed states.
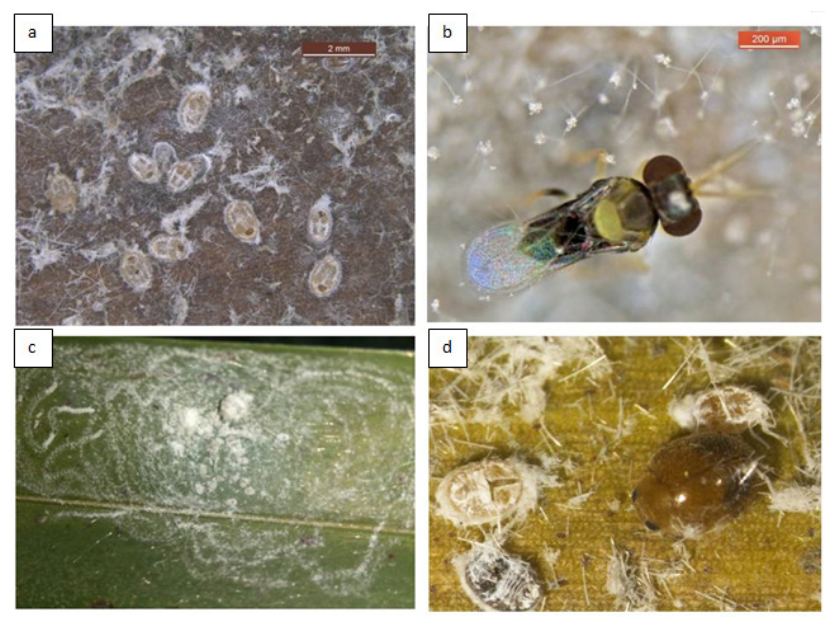

Plate 2. Natural enemies of Aleurodicus rugioperculatus. a. Parasitized pupae; b. Adult parasitoid of Encarsia guadeloupae; c. Mallada sp; d. Coccinellids.

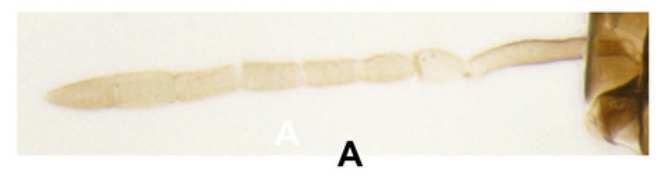

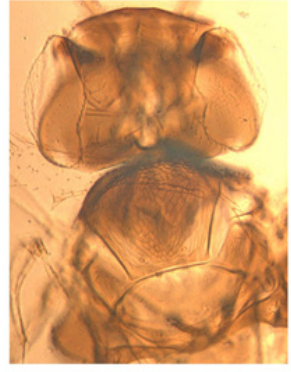

B

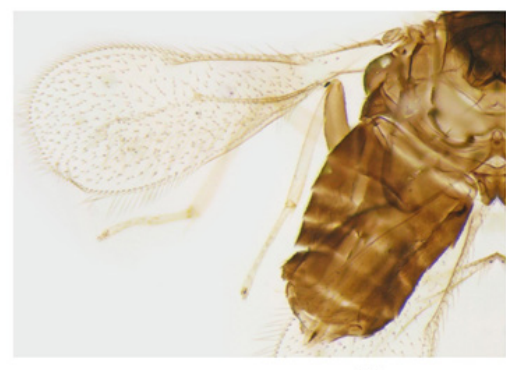

C
Plate 3. Key diagnostic characters of female Encarsia guadeloupae Viggiani.

\section{Extent of invasion and damage in India}

Presently, infestation of RSW increased over the time and spread across the southern states in India except Karnataka (surveyed sites- Chamrajnagar, Kollegal, Maddur and Mandya) and extending its host ranges at greater level which could be due to its polyphagous nature. Immature stages of RSW produce profuse quantity of wax filaments both tufts of fluffy and long crystal like glassy rods. Furthermore, RSW produce honey dew in severe condition which results in development of sooty mould. Across the survey locations, the severity of infestation ranged 40-60 $\%$ in coconut and $25-40 \%$ of leaf in banana and population including all the immature stages varied from 18 to 43 nymphs/sq.cm of leaf and very high at midrib region. Complete drying of banana leaves were also noted in several places in Tamil Nadu and Kerala. This communication reports occurrence of the pest, its host plant range and associated natural enemies for the first time in India.

\section{ACKNOWLEDGEMENTS}

We are grateful to the Indian Council of Agricultural Research, New Delhi for research support. Thanks to Dr. Mohammad Hayat, AMU, Aligarh for prompt clarification and literature aid provided for parasitoid identity. Similarly, we also thank the Curator, Mahatma Gandhi Botanical 
Garden, UAS, GKVK, Bengaluru for identification of host plants.

\section{REFERENCES}

Evans GA. 2008. The whiteflies (Hemiptera: Aleyrodidae) of the world and their host plants and natural enemies. Available from: http://keys.lucidcentral.org/keys/v3/ whitefly/ PDF_PwP\% 20ETC/world-whitefly- catalog-Evans.pdf

Dickey AM, Stocks IC, Smith T, Osborne L, McKenzie CL. 2015. DNA barcode development for three recent exotic whitefly (Hemiptera: Aleyrodidae) invaders in Florida. Florida Entomol. 98(2): 473-478.

Francis AW, Stocks IC, Smith TR, Boughton AJ, Mannion CM, Osborne LS. 2016. Host plants and natural enemies of rugose spiraling whitefly (Hemiptera: Aleyrodidae) in Florida. Florida Entomol. 99(1): $150-153$.

Hayat M. 2011. Additions to the Indian Aphelinidae (Hymenoptera: Chalcidoidea) - III: The genus Encarsia Förster. Oriental Insects 45: 202-274.

Hebert PDN, Penton EH, Burns JM, Janzen DH, Hallwachs W. 2004. Ten species in one: DNA barcoding reveals cryptic species in the neotropical skipper butterfly Astraptes fulgerator, PNAS. 101(41): 14812-14817.

Kumar V, McKenzie CL, Mannion C, Stocks I, Smith T, Osborne LS. 2013. Rugose spiraling whitefly, Aleurodicus rugioperculatus Martin (Hemiptera: Aleyrodidae). EENY578. University of Florida, IFAS Extension. Available from: http://entnemdept.ufl.edu/ creatures/orn /Aleurodicus_rugioperculatus.htm
Martin JH. 2004. The whiteflies of Belize (Hemiptera: Aleyrodidae) Part 1 - Introduction and account of the subfamily Aleurodicinae Quaintance and Baker. Zootaxa. 681: 1-119.

Sundararaj R, Selvaraj K. Invasion of rugose spiraling whitefly, Aleurodicus rugioperculatus Martin (Hemiptera: Aleyrodidae): A potential threat to coconut in India. Phytoparasitica (In Press).

Stocks I. 2012. Rugose spiraling whitefly host plants. Florida Department of Agriculture and Consumer Services (FDACS), Division of Plant Industry (DPI). Available from: http://monroe.ifas.ufl.edu/pdf/Hort/ RSW_Host_Plants_May_2012.pdf

Stocks IC, Hodges G. 2012. The rugose spiraling whitefly, Aleurodicus rugioperculatus Martin, a new exotic whitefly in south Florida (Hemiptera: Aleyrodidae). Florida Department of Agriculture and Consumer Services, Division of Plant Industry. Available from: http://freshfromflorida.s3. amazonaws.com/ aleurodicusrugioperculatus-pest-alert.pdf

Taravati S, Mannion C, Glenn H, Osborne L. 2013. Natural enemies of rugose spiraling whitefly, Aleurodicus rugioperculatus Martin (Insecta: Hemiptera: Aleyrodidae) in the south Florida landscape. ENY870. University of Florida, IFAS Extension. Available from: http://edis.ifas.ufl.edu/pdffiles/IN/IN100400. pdf

Viggiani G. 1987. New species of Encarsia Förster (Hymenoptera: Aphelinidae), parasitoids of whiteflies. Bollettino del Laboratorio di Entomologia Agraria 'Filippo Silvestri'. Portici. 44: 35-37. 